\title{
İnanç Turizmi Faaliyetlerine Yönelik Olumsuz Etki Eden Faktörlerin Araştırılması: Kastamonu Örneği
}

\author{
Yüksek Lisans Öğrencisi Oğuz ÇAM \\ Kastamonu Üniversitesi, Sosyal Bilimler Enstitüsü \\ oguzcam911@gmail.com \\ https://orcid.org/0000-0003-3222-3367 \\ DOI: https://doi.org/10.37847/tdtad.827349 \\ Makale Gönderim Tarihi: 17.11.2020
}

\author{
Dr. Öğr. Üyesi Muharrem AVCI \\ Kastamonu Üniversitesi, Turizm Fakültesi \\ mavci@kastamonu.edu.tr \\ https://orcid.org/0000-0002-0264-1181 \\ Makale Türü: Araştırma Makalesi \\ Makale Kabul Tarihi: 02.12.2020
}

\section{Özet}

Bu çalışma; Kastamonu' daki inanç turizmine yönelik olumsuz etki eden faktörlerin araştırılması amacıyla oluşturulmuştur. Çalışma kapsamında nitel araştırma yöntemi kullanılmış ve söz konusu çalışma doküman analizi tekniğiyle değerlendirilmiştir. Bu çalışma neticesinde inanç turizmine yönelik olumsuzluklar ve problemler ortaya konulmuştur. Kastamonu ili, doğal, tarihi, kültürel ve dini değerler bakımından önemli potansiyele sahip olmaktadır. Şehirde tanıtım sorunu ile beraber birçok sorun olması inanç turizmi ve bundan dolayı da turizmi olumsuz etkilemektedir. İnanç turizminin gelişmesini engelleyen birtakım problemlerin aşılmasıyla bu turizm türünden olabildiğince yüksek gelir elde edileceği tahmin edilmektedir. Bu çalışma Kastamonu'nun inanç turizmi alanıyla ilgili çalışma yapacak kişilere önemli kaynak teşkil etmektedir.

Anahtar Kelimeler: Kastamonu, Turizm, İnanç Turizmi, Olumsuzluk, Problem.

\section{Investigation of Factors That Negatively Affect Faith Tourism Activities: The Case of Kastamonu}

\begin{abstract}
This work; It was created in order to investigate the factors that have a negative effect on faith tourism in Kastamonu. Within the scope of the study, qualitative research method was used and the study in question was evaluated with document analysis technique. As a result of this study, the negativities and problems regarding faith tourism were revealed. Kastamonu province has an important potential in terms of natural, historical, cultural and religious values. The fact that there are many problems with the publicity problem in the city affects faith tourism and therefore tourism negatively. It is estimated that the highest possible income will be obtained from this type of tourism by overcoming some problems that prevent the development of faith tourism. This study constitutes an important resource for those who will work on the field of faith tourism in Kastamonu.
\end{abstract}

Keywords: Kastamonu, Tourism, Faith Tourism, Negation, Problem.

\section{GİRIŞ}

İnanmak insanın fitratında var olmaktadır. İnsanlar var olduktan itibaren, kendilerinde hep inanma ihtiyacı hissetmişlerdir. İnanç, kişilerin iç sesinden gelen bir istek ve gereksinim dürtüsüdür. İnanç çerçevesinde öne çıkan belli başlı çekim merkezleri, dini yapılar, şahıslar, olaylar olmaktadır. Türkiye'de inanç kavramı denilince akıllara Kastamonu ili gelmektedir. Yapısı içerisinde bulunan, cami, mescit, türbe, külliye, mabet, ziyaretgâh ve benzeri yapıların yoğun olması nedeniyle önem inanç turizmi açısından önemli bir potansiyel teşkil etmektedir. Kişiler bu tür yapılara ziyaret gerçekleştirmektedir. Bundan dolayı kentte yapılan inanç turizmi faaliyetlerinin geliştirilmesi ve reklam, tanıtım etkinliklerinin daha etkin bir şekilde yürütülmesi 
gerekmektedir. Şehirdeki inanç turizmi konusunda izlenen yolda yeni fikirler öne sürülmeli ve geliştirilmelidir.

İnsanların turizm konusunda düşüncelerine olumsuz etki eden birtakım problemlerin ortadan kaldırılması gerekmektedir. Bu anlamda en büyük yük turizm paydaşlarına düşmektedir. Sosyal ve etik kurallara uyularak, turistlere yönelik gerçekleştirilecek suçların önüne geçilerek, yöresel halk turizm konusunda yeterli seviyede bilgilendirilip bilinçlendirilerek turizm sektöründen güzel bir gelir elde edilebilir.

İnanç turizmi kapsamında Kastamonu'ya seyahat gerçekleştiren turistler, öncelikle, can ve mal güvenliğinin tehlikede olmamasına dikkat etmektedir. Ulaşım imkânlarının zengin ve yeterli olmasına önem vermektedir. İletişim ve haberleşme sorunlarının yaşanmamasını istemektedir. Kastamonu Belediyesi, Kastamonu Üniversitesi, yerel halk ve girişimciler aracılığıyla şehirdeki inanç turizmi faaliyetleri önemli derecede gelişme gösterecektir.

\section{LITERATÜR İNCELEMESI}

İnsanoğlu yaratıldığ1 ilk andan itibaren, herhangi bir dine ait olma gereksinimi duymuştur. Bundan ötürü, insanoğlunun dünyada var oluş tarihine bakıldığında pek çok farklı din grupları ve inanç gruplarının ortaya çıktığı görülmektedir. Böylece mukaddes yerler insanlar tarafından kitlesel hareketlerle ziyaret edilmiştir. Bu hareketler neticesinde seçenek bir turizm olgusu olan inanç turizmi doğmuş bulunmaktadır (Güzel, 2010: 90). İnanç turizmi, insanların inançları gereği dini vazifelerini yerine getirmek ya da ziyaret gerçekleştirmek amacıyla dini bakımdan önemli buldukları mukaddes yerleri minimum bir gece konaklamalarından oluşan geçici seyahatlerin meydana getirdiği sosyal ve ekonomik nitelikli olaylar ve ilişkiler bütünü olmaktadır (Karaman ve Usta, 2006: 473). Kişilerin inançlardan etkilenerek seyahat gerçekleştirmeleri inanç turizmi kapsamında değerlendirilmektedir (Rinschede, 1992: 34). İnanç turizmi, Paris, Notre Dame'ye ziyaretlerden hac ziyaretlerine değin birçok farklı faaliyeti ihtiva eden bir olgudur (Griffiths, 2011: 63). Mukaddes yerlere ziyaret gerçekleştiren turistler, dinsel tecrübe edinme ve mukaddes bir ortamda bulunma arayışı içindelerdir (Shackley, 2002: 348). Başka mezheplere veya dinlere mensup bulunan turistler, eğitim maksatlı veya yalnızca merak unsurundan ötürü dini destinasyonlara ziyaret gerçekleştirmektedir (Nolan ve Nolan, 1992: 71).

Haricilerle başlayan İbn Teymiyye, Kadızadeliler, Vehhâbilik, el-Kaide, Daeş biçiminde geçmiş zamandan günümüze gelişme göstererek devam eden selefi tekfirci dini gurupların (Yıldırım, 2019a: 91-110) olumsuz tavırlarına karşın, tevessül ve teberrük (Söz konusu iki kavram için bkz. Kırış, 2011: 19-30; Yıldırım, 2019b: 229) amaçlı inanç turizmi bütün engellemelere rağmen gelişme göstermektedir. Bu anlayışı kültürümüzdeki "evliya” inancı beslemektedir. (Güngör, 1972: 8-12). Cumhuriyet döneminin önemli şairlerinden Süleyman Nazif (v. 1927) Kastamonu valisi iken Hz. Pîr'i sık sık ziyaret eder ve şu tespitte bulunur: " $B u$ zâttan ilmî bir neşve, ledünnî bir haz duymaktan halî olamıyorum. Anllyorum ki, bu büyük zât gönüller fetheden hâlâ ruhlarımıza hâkim olan bir mutasavvıftır. Bulanık bir yürekle huzuruna giriyor, tertemiz bir vicdanla lahdinden uzaklaşıyoruz" (Aşkar, 2012: 140-141). Bu duygularla "Huzuru Pîr'e yüz sür itilâ iderse vicdânın" biçiminde bir mısra-i berceste söyler. Bu misra siyah zemin üzerine altın yaldızla ve ta'lik hattıyla yazılıp türbenin hâlen mevcut olmayan hol kapısının üzerine konulur. 1925'te kaldırılıp ziyana uğratılır. (Ozanoğlu, 1966: 13). Muharrem Avcı'ya göre bu değerli parça müzeye konulmuştur. (KK1) Bugün bu mısra türbe girişinin karşısında ahşap bir çerçevede sergilenmektedir. Şiirin beyit olarak tamamı şu şekildedir (Aşkar, 2012: 141):

Bu Şa'bân-ı Velî'dir ki muktedâ-yı feyz-i irfânın, Huzûru pîr'e yüz sür itilâ ister ise vicdânın.

Kavram olarak din, tarihsel hadiseler, kültür, yaşam toplumun en geniş biçimde algılanması ve gene kişilerin tarihteki süreçlerine dair daha derin bakış açısı sağlamaktadır (Kelly, 1982: 128; Rzazade, Guzel ve Ehtiyar, 2018: 428). Kültürün bir ana öğesi olan din, insan yaşamının türlü 
öğeleriyle ilişkilidir ve yeme-içme faaliyetleri, giyim-kuşamı, sosyal tutumu, siyasi görüşü, seyahat motivasyonları ve seyahat davranışlarını etkileyebilmektedir (Levin, 1979: 9; Mattila vd., 2001: 195; Poria, Butler ve Airey, 2003: 239; Rzazade vd., 2018: 428).

Tala ve Padurean (2008: 246), inanç turizmi paydaşlarını 'uluslararası organizasyonlar, yerel toplum, dini topluluklar, hükümetler, yerel yetkililer ve altyapı yöneticileri, akademik çevre, yerel turizm hizmeti sağlayıcıları, iç-dış tur operatörleri, transfer şirketleri ve diğer özel sektör paydaşları" olarak tasnif etmektedir. Bu tasnif içerisinde bulunan her bir paydaş, varış yerinde inanç turizminin tanıtılması ve gelişmesi noktasında ortak vizyon geliştirerek, hedef, izlem ve misyon belirleyerek hareket etmelidirler.

Hem yurdumuzun doğal ve kültürel zenginliklerini tanımak, hem de Anadolu'daki kalıntılarını görmek, dinlenmek, eğlenmek, tatil yapmak, dolaşmak ve benzeri maksatlarla her sene yerli ve yabancı ziyaretçilerin Türkiye'de turistik amaçlı seyahat gerçekleştirdiği bilinmektedir. Bu ziyaretçilerin çoğunlukla aradıkları; kendi hayatlarını devam ettirdikleri yerlerde bulamadıkları, duyup görmeyi istedikleri değerler ile doğanın içtenliğine sığınabildikleri yöreler olmaktadır. $\mathrm{Bu}$ yönden bakıldığında Kastamonu ilinin sunmuş olduğu turizm arzı, her ziyaretçi tipine uyum göstermektedir. Fakat çeşitli yöntemler ile anlatma ve tanıtma etkinlikleri yeterli durumda bulunmadığından dolayı ziyaretçiler bu şehir konusunda hiç bilgi sahibi olmamakta ya da yanlış düşüncelerin meydana gelmesine ve Kastamonu kent imajının bozuk bir şekilde ortaya çıkmasına sebep olmuştur (Avc1, 1990: 37). Evliyalar Kenti olarak da bilinen Kastamonu, inanç turizmi bakımından da oldukça önemli olmaktadır. Özellikle, Türk-İslam tarihinin Anadolu'daki ilk adımları olan evliyaların ömürlerini geçirdikleri ve konakladığı yerlerin mukaddes olmaları bakımından konuya yaklaşılacak olduğunda; Kastamonu ili, Bursa ve Konya gibi dini niteliğe sahip olan kentlerden hemen sonra gelmektedir. Şehirde birçok türbe ve ziyaretgâh bulunmaktadır. Hatta çok kıymet verilen, saygı duyulan yakın geçmişlerde yaşamış din adamlarının da ziyaretçileri bulunmakta ve bu ziyaretçilerde iç turizm açısından son derece önemli olmaktadır (Avc1, 1990: 37).

Kastamonu kenti, doğal ve tarihi yapısıyla turizm bakımından dikkatleri üzerine çekebilecek bir yöre görünümünde olmaktadır. Fakat şu ana kadar, kentin içine kapanık olması, temel geçiş noktalara ve Türkiye turizminin odaklandığı bölgelere yakın konumda yer almaması ve şehir insanlarının turizm konusunda yeterli bilgiye sahip olmaması ve benzeri sebepler, Kastamonu'yu turizm açısından bir köşede beklemeye itmiş bulunmaktadır. Kastamonu yerel halkı; turizmin doğuş ve gelişimleri hakkında bilgi sahibi olmadığından, turistlerin kendilerine gelmesini beklemekte ve turisti şehirde gördüğü vakit, ancak girişimlerine yönelmektedir. Öncelikli olarak bu fikirlerin değiştirilmesi, bekleyici değil de davet edici bir zihniyetin yerleştirilmesi gerekmektedir. Kastamonu, girişimciliği zayıf turizm sektörü yapısıyla hemen kazanç sağlamaya dönük turizm zihniyeti, öncelikle ele alınması gereken sorunlardır. Kastamonu ilinin turizm alanında etkili bir koordinasyon sağlaması gerekmekte, kamu kurum/kuruluşların, girişimcilerin, turizm ve basın-yayın organlarıyla alakalı her türlü derneklerin birbirleriyle haberli çalışmalarını sağlamak, onlar içerisinde iş bölümü oluşturmaya çalışmak gerekmektedir. Gönüllü turizm ekipleri oluşturmak, ilin tarihini ve doğal dokusunu tanıtıcı kısa süreli gezi uygulamaları gerçekleştirmek ve bu sayede yöreyi tanıtmak akılcı fikirler arasında sayılabilmektedir. Kastamonu kentinin tanıtımı; herhangi bir bireyin veya kuruluşun yapabileceği bir mesele olmayıp, bütün Kastamonu halkının elbirliğiyle meydana getirecekleri muhteşem bir organizasyonla mümkün olabilecektir. Kentin tarihi yapısını göz alıcı bir şekilde gösteren broşüler tasarlanmalı, turizm türlerine göre sınıflandırılarak hedef kitlelere ulaştırılması sağlanmalıdır. Tanıtım faaliyetlerinin yürütülebilmesi için maddi, manevi işbirliğine gereksinim duyulmaktadır. Turizm ürünü, herhangi bir ülkenin doğal yapılarının ve tarihi zenginliklerinin yanı sıra, buraları ziyarete gelen kişilere sunulan hizmeti de kapsayan toplam bir bütün olmaktadır. Bu durum Kastamonu açısından değerlendirildiğinde; şehrin doğal ve tarihi yapılarının uygun, fakat hizmet birimlerinin eksik ve fazla nitelikli olmadığ görülmektedir. İl üzerinde gerçekleştirilen turizm çalışmalarının gelişebilmesi için, hizmet 
birimlerine çok önem verilmeli ve geliştirilmelidir. Kastamonu ilinin turizme bakış açısı olsun, turizm sektöründe çalışanlar olsun, konuya ilişkin durumlara sadece ekonomik açılardan bakma ve kısa zaman dilimi içerisinde kar sağlama amacında oldukları görülmektedir. Dolayısıyla bu fikir birçok sorunun ortaya çıkmasına sebep olmaktadır. Bu bakımdan şehirde turizm bilincinin oluşturulması ilk hedef olmalı ve dikkat çekmelidir. Ardından bilgili, deneyimli, yetenekli, görgülü, yabancı dil bilen nitelikli personellerin yetiştirilerek onların istihdamının sağlanması, eğitim çalışmalarının hedef noktalarını ortaya çıkarmaktadır. Turizm konusunda uzman kişiler Kastamonu iline davet edilmeli, seminer, konferans ve eğitim programları düzenlenmelidir. Kastamonu kenti turizme yönelik yapılan yatırımlar açısından oldukça fakir olmaktadır. Kastamonu'da nitelikli hizmet işletmelerinin inşa edilmesi, gerekli görülen yapılara yenileme çalışmaları yapılarak turizme açılması, kentin turizm talebini artırabilecek öğeler olarak düşünülebilmektedir. Fakat bu tür yatırımlar oluşturulurken, doğal ve tarihi çevrenin zarar görmesini engellemek olabildiğince önem arz etmektedir. Aksi halde yalnızca taş yığınlar içerisinde kalmış, doğal ve tarihi görünümü yok olmuş bir oluşumla karşı karşıya kalınabilir, bu tür bir görünüm de turistlerin kesinlikle uygun bulmadığı bir manzara olmaktadır (Avcı, 1990: 69-71).

Pazarlama ve tanıtım problemleri; reklam ve tanıtım çalışmalarının pazar üzerindeki tesiri, potansiyel talebin fiili talebe dönüştürülememesi, ertelenmiş olan talebin turizm faaliyetlerine katılma konusunda motive edilmesi, bilgi eksikliklerinin ortadan kaldırılarak fiili talep meydana getirilmesine çalışılması veya fiili talep oluşturanların daha çok seyahat gerçekleştirmesine teşvik edilmesi şeklinde somutlaştırılmaktadır (Demirkol, 2004: 136).

Bir turistik ürünün tüketicilere ulaştırılmasında en önemli faaliyet, pazarlama çabaları olmaktadır. Pazarlama faaliyetlerinin etkili bir şekilde yürütülemediği destinasyon ya da ülkenin başarı göstermesi mümkün olmamaktadır. Turistik arz imkânları yeterli oranda olmasına karşın, istenilen seviyede turist çekemeyen varış yerleri, en mühim problemi pazarlama alanında yaşamaktadır. Yurt içinde ve yurt dışında etkin biçimde tanıtılamayan varış yerlerinde, turist gelişlerinde istenilen artışlara ulaşılamamaktadır (Tunçsiper ve İlban, 2006: 225).

Etkin pazarlama etkinlikleri için değerlendirilebilecek yöresel turizm pazarlamaları, genel pazarlama izlemleri yerine kentsel ve bölgesel tanıtım ve pazarlama etkinliklerine, pazardaki rakipler ile mücadele etmeye ve kaynakların etkili kullanılmasına ağırlık vermektedir (Tosun ve Bilim, 2004: 272).

Eğitilmiş işgücü problemleri; Hizmet işletmelerinin birçoğu, gereğinden daha fazla sayıda çalışanı istihdam etmekte ve turistlere sundukları hizmetleri çoğunlukla emek yoğun bir biçimde gerçekleştirmektedir. Bundan dolayı turistlere sunulan hizmetin kalitesi, direkt olarak personellerin nitelikleri ve kaliteleri ile yakından alakalıdır. Eğitilmiş ve nitelikli personel çalıştıran hizmet işletmelerinde, hizmet kalitesi artış göstermekte ve bir nevi işletmeye gelen turistlerin devamlılı̆̆ sağlanmaktadır. Eğitilmiş işgücü arzı bakımından Türkiye'de herhangi bir problem olmamaktadır. Lise ve üniversite seviyesinde turizm sektörünün gereksinimini karşılayacak istenilen nitelik ve düzeyde işgücü yetiştirilmektedir (Hacıoğlu vd., 2008: 153).

Altyap1 ve üst yapı problemleri; bir yerin turistik destinasyon olabilmesi için ilk olarak turistik ürüne/ürünlere sahip olması gerekmektedir. Nitelikli turistik ürünün olduğu bir bölgenin varış yeri olabilmesi için ise altyapı (ulaşım, iletişim, elektrik, su vb.) ile üst yapı (alışveriş imkânları, turistik tesisler, aktiviteler vb.) yatırımlarına gereksinim duyulmaktadır. Altyapı ve üst yap1 yatırımlarının yeterli seviyede olması, bir bölgede turizm hareketlerinin gelişebilmesi bakımından önem arz etmektedir (Hacıoğlu, 1991: 23). Gerçekleştirilen pek çok çalışmada (Duman ve Öztürk, 2005: 12; Kaşlı, 2006: 265; Akkılıç ve Günalan, 2007: 125; Çakıcı, Atay ve Aksu, 2008: 87), herhangi bir varış yerini ziyaret eden turistlerin şikâyet ettikleri konuların en başında altyapı ve üst yapıyla alakalı, bilhassa ulaşım ile alakalı problemlerin bulunduğu ortaya konulmaktadır (İlban ve Kaşl1, 2011: 30). 
Hizmet kalitesi problemleri; turizm işletmelerinin, dolayısı ile içinde oldukları turistik varış yerlerinin başka bir problemi de turistlere gösterilen hizmetin kalitesi olmaktadır. İşletmeler tarafindan turistlere sunulan hizmetin kalitesinde yaşanan problemler, mühim ölçüde turistlerin tekrar ziyaret etme arzusunu sona erdirdiği bilinmektedir (Duman ve Öztürk, 2005: 13). Bu noktadan hareketle turizm işletmelerinin turistlerin memnuniyetlerini sağlamalarını, işletmelere finansman sağlama ve pazarlama maliyeti konusunda avantaj sağlayacağını ifade etmek mümkün olmaktadır (İlban ve Kaş11, 2011: 30).

Ürün geliştirme problemleri; bir varış yerinde ürüne dönük yaklaşım, ürün ne denli uygun olursa olsun, turistlerin varış yerine gelmesini sağlayan tek çekicilik unsuru olarak görülmemeli, sürekli geliştirilmelidir. Her varış yeri, kendisine has olan kaynaklar, ihtiyaçlar ve değerleriyle benzersiz ürün karmasına sahip olmaktadır (İlban ve Kaşl1, 2011: 32). Jamieson (2006: 8-9), varış yeri pazarlamasının başarılı olabilmesi için, bir turistik üründe eşsiz-benzersiz deneyimler ve misafirperverlik arayan turistler için çekiciliklerin bulunması gerektiğini ifade etmektedir.

Fiyat çeşitliliği problemleri; herhangi bir varış yerinin turistler tarafından tercih edilmesine etki eden en mühim etkenlerden biri olarak, fiyat gösterilebilmektedir. Varış yerindeki farklı seçenek fiyat uygulamaları tüketicilerin satın alma karar süreçlerine etki eden ve turistik ürünün satın alınmasını kolaylaştıran en mühim etmenlerden bir tanesi olmaktadır. Farklı gelir gruplarından olan tüketicilerin turistik ürünleri satın alabilmeleri için, farklılaştırılmış ürün fiyatlarının olması önemli olmaktadır. Bu sebeple fiyatın satın alma karar sürecindeki hassas rolünün, varış yeri yönetimleri tarafindan daima dikkate alınması gerekmektedir (İlban ve Kaş11, 2011: 32).

Finansman problemleri; emek yoğun bir çalışmanın ve alınan ücretlerin oldukça yüksek olduğu turizm sektöründe, varış yerlerinin ve işletmelerin karşılaştığı problemlerin bir başkası da finansman problemleri olmaktadır. Finansman, varış yeri yönetiminin mühim bir sorumluluk alanı olmaktadır (Jamieson, 2006: 12). Bilhassa mevsimsel özelliklere göre turistik faaliyetlerde değişmelerin yoğun olarak gerçekleştiği varış yerlerinde bu problem çok daha büyük olmaktadır. Turistik talebin dalgalı bir ilerleyiş göstermesi, işletmelerin finansal planlama yapmalarını güçleştirmekte ve işletmeler finansal krizler ile baş başa kalmaktadır (Kaşlı ve Karataban, 2008: 145).

Davranış ve güvenlik problemleri; turizm, turistik etkinliklere katılan bireylerin hayatını sürdürdükleri bölgelerden başka yerlere seyahat gerçekleştirmeleri ve konaklamalarını ihtiva etmektedir. Dolayısı ile turizm faaliyetlerine katılan kişilerin alışagelmiş bir hayat ve kültürden farklı bir hayatın ve kültürün olduğu bir yere hareket etmeleri söz konusu olmaktadır. Bu hal, bazı zamanlarda turizm varış yerlerinde turistler ve yerli halk arasında sosyal çatışmaya dönüşebilmekte ve kimi zamanlarda çeşitli sebepler ile turistlere yönelik suçlar işlenebilmektedir. Bu tür bölgelerde turizm faaliyetlerinden elde edilebilecek kazanımlar (bunlar bilhassa, çevresel, kültürel, politik ve sosyo-ekonomik olarak boyutlandırılabilmektedir), yerel halk tarafindan turist, turist tutumlarının ve ayrıca turizm hareketlerinin ne denli kabul edildiği ile yakından alakalı olmaktadır (Nepal, 2008: 46-47). Herhangi bir turizm destinasyonunda turistlere yönelik işlenen suçlar, o destinasyonun imajına olumsuz yönde etki edebilmekte ve turistler tarafindan güvenlik problemi olduğu düşünülen destinasyonlara beklenen seviyede turist gelişleri sağlanamamaktadır (Duman ve Öztürk, 2005: 15; Kaşl1, 2006: 268; İlban ve Altay, 2008: 204).

Dünyada şehirleşme ve sanayileşme neticesinde kültürel ve doğal varlıkların tahribi hızlı bir şekilde artmış, bunun neticesinde çevre koruma olgusu gündeme gelmiş bulunmaktadır. Bu noktada turizmin temel kaynaklarından kültürel ve doğal zenginliklerin muhafaza edilmesi önem kazanmıştır. Doğal kaynakların ve kültürel kaynakların devamlılığının sağlanmasının ana hedef olduğu bir turizm yaklaşımında fiziki planlama kararları da koruma ve kullanma dengesini sağlar kalitede olacaktır. Tarihi çevrelerin muhafaza edilmesinde, çok kapsamlı bir koruma planı gerçekleştirilip uygulanmadığından doğal ve kültürel miras, günün değişiklik gösteren ekonomik şartları yönünde kullanılmakta ve yıpratılmaktadır. Bunların önüne 
geçilmesi için tarihi şehirde yapılan fiziksel planlama faaliyetleri koruma öncelikli anlayış içerisinde yapılmalıdır (Kuter ve Erdoğan, 2006: 118).

Turizmin gelişmesi için ilk olarak, mevcut toplumsal yapının inşa edilmesi gerekmektedir. Burada önemli olan noktaysa turizm olgusunun beslendiği temel zemin yani toplum öğesidir. Öyle ki, toplumların tutumları, sosyal donanımları, kadınların sosyal statüsü, inanç sistemi, ahlak kuralları, güvenlik ve sağlık seviyeleri, eğitim ve dil düzeyleri, demografik yapısı, yaşam kalitesi, örgütlenme biçimleri, nüfus yoğunluğu ve kültürel değerleri gibi özellikler turizm sektörünün gelişmesinde ve çıktılarının dağılımında mühim bir etkileşim alanı meydana getirmektedir (Avcıkurt, 2009: 31). Toplumsal kapasite, gücünü toplumdan sağlayan ve bu gücü tekrar toplumsal gelişme üzerine adapte eden bir döngü ihtiva etmektedir. Bunlara göre toplumsal kapasitenin temel dayanak noktaları; beceriler, bilgi seviyesi, liderlik, değer sistemi, sosyal yap1, sosyal diyalog, toplumsal katılım, toplumsal ilişkiler ve öğrenme kültürü olur iken (Sznycer-Taub, 2009), turizmde gelişmelerin elde edilmesi bu öğeleri genel bir çerçeve içerisinde sunan toplumsal kapasiteyle alakalı olmaktadır (Liu, 2006).

\section{METOT}

Araştırmanın Yöntemi: $\mathrm{Bu}$ çalışma kapsamında nitel araştırma yönteminin kullanılması planlanmıştır. Doküman analiziyle söz konusu çalışma değerlendirilmiştir.

Araştırmanın Veri Toplama Aracı ve Analizi: Veri toplama aracı ve analizi doküman analizi tekniğidir. Kastamonu örneği konulu olan bu çalışma kapsamında önceden gerçekleştirilmiş; bildiri, makale, tez ve kitaplar üzerinden bilgiler toplanmıştır. Kastamonu' daki inanç turizminin önündeki engellere, olumsuzluklara dair bilgiler belirlenmeye ve ifade edilmeye gayret gösterilmiştir. Elde edilecek veriler tarafsız bir şekilde analiz edilmiştir. Araştırma neticesinde, Kastamonu ve inanç turizmi arasındaki bağların kuvvetleneceği hususunda bir izlenim yaratılacağı tahmin edilmektedir.

Araştırmanın Problemi: Kastamonu ilinin turizm açısından geliştirilmeye ihtiyacı bulunmaktadır. İnanç turizmi destinasyonu olarak pek çok turizm arzı bulunmaktadır. Fakat etkili bir şekilde tanıtım, reklam, ürün, fiyat, tutundurma, dağıtım hizmetleri yeterli görülmemektedir. İnanç turizmi etkinlikleri ve faaliyetleri gerek şehir içinde, gerekse de şehir dışında pek fazla bilinmemektedir. Bunda tanıtım çalışmalarının etkili gerçekleştirilememesi, inanç turizmi faaliyetlerini sekteye uğratan, engel teşkil eden problemlerin ortadan kaldırılamaması ve kitle iletişim araçların yeterince etkili kullanılamaması ilde öne çıkan problemlerden birkaçı olmaktadır. Bu problemlerin tespit edilerek, uygun çözüm yollarının üretilmesi, yöredeki insanlar üzerinde bilinçlendirmelerin hedeflenmesi, ilde turist sayısının az olması ve artırılmak istenmesi bu problemlerin odak noktalarını oluşturmaktadır.

Araştırmanın Amacı: $\mathrm{Bu}$ araştırma, Kastamonu ilinde gerçekleştirilen inanç turizmi faaliyetlerine yönelik olumsuz etki eden faktörlerin araştırılması ve bu konu ile ilgili insanları bilinçlendirmeye dönük çalışmaların geliştirilmesi amacıyla oluşturulmuştur. Kastamonu ilinde turizmin geliştirilmesi için yerel halk, basın-yayın organları, girişimciler, kurum ve kuruluşların iş birliği çerçevesinde gerekli faaliyetleri yürütülmesinin önemine dikkat çekmek amaçlanmaktadır. İlde turizm denilince, inanç turizmi potansiyelinin yüksek olmasından dolayı akıllara ilk gelenler arasında inanç turizmi gelmektedir. Kastamonu kentindeki inanç turizmi faaliyetleri önündeki engellerin ortadan kaldırılmasıyla turizm sektöründen alınan pay da daha yüksek olacaktır. İnanç turizmi maksatlı gerçekleştirilen ziyaret oranlarında artmalar sağlanabilecek ve bölgenin daha çok ekonomik kazanç elde etme hususunda avantajları bulunabilecektir.

Araştırmanın Önemi: Kastamonu İlinde inanç turizm faaliyetlerine katılacak olan turistlerin sayılarında artış sağlanması için önem arz etmektedir. Hal böyle olunca şehir ekonomisinde çok büyük kazançlar sağlanabilecek ve ilin tanınırlı̆̆ında avantajlar elde edilebilecektir. Anadolu'nun dört manevi direğinden bir tanesi olan Hz. Pir Şeyh Şaban-1 Veli'nin ulusal 
platformlarda daha geniş kitleler tarafından bilinebilmesi açısından da son derece önemli olmaktadır. Kastamonu'da inanç kavramı denildiğinde akıllara dini açıdan önemli şahsiyetler, mabetler, ziyaretgâhlar, türbeler, külliyeler ve benzeri gelmektedir. İnsanlar arasında ' 'Evliyalar Kenti' olarak da tanınan Kastamonu'nun, sahip olduğu doğal ve kültürel miraslarının ulusal çapta bilinebilmesi, bölgeye daha çok ziyaretçi çekilebilmesi, gelenek-göreneklerin yaşatılabilmesi, insanlar üzerinde uhrevi bir ruh hali oluşturularak kültürel zenginliğin artırılması, inanç, turizm ve barış kavramlarına vurgu yapılarak gerek bölgesel gerekse de ulusal anlamda bilinçlendirilmeye dikkat çekilebilmesi açısından önemlidir.

\section{BULGULAR}

Tablo 1. Bulgular Tablosu

\begin{tabular}{|c|c|}
\hline Yabancı Dil Faktörü & $\begin{array}{l}\text { Günümüz çağında iletişim kurabilmenin önündeki en büyük engeller arasında } \\
\text { yabancı dil bilmeme gelmektedir. Turizm sektöründe yabancı dil öğrenimine } \\
\text { çok önem verilmektedir. Bu konuda yabancı turistler ile haberleşme ve } \\
\text { iletişim kurmada sıkıntılar ve olumsuzluklar yaşanabilmektedir. İnanç turizmi } \\
\text { alanında da dil öğrenimi birçok kolaylıklar sağlayabilmektedir. Insanlar ne } \\
\text { kadar çok anlaşılldığını anlar ise, o derece kendilerini mutlu hissetmektedir. } \\
\text { Kastamonu ilinin, yabancı dil öğrenimi alanında çeşitli yeniliklere ve } \\
\text { gelişmelere gereksinimi bulunmaktadır. Yabancı dil bilinmediği takdirde ise, } \\
\text { turist ile yerli halk arasında sağlklı iletişim kurulamamaktadır. Turistlere } \\
\text { karş1 söz konusu olan il etkileyici ve tatmin edici güzellikleriyle ifade } \\
\text { edilmediği ya da edilemediği sürece turizm alanında gelişme } \\
\text { gösteremeyecektir. Şehir; tarihi, dini, kültürel değerlerin çok olması } \\
\text { bakımından inanç turizmi ve kültür turizmi açısından önemli merkezlerden } \\
\text { sayılabilmektedir ancak yabancı dilin bilinmemesi ya da az bilinmesi } \\
\text { turistleri memnun etmemekte, onları düşüncelerinde iyi bir izlenim } \\
\text { bırakmamaktadır. Kastamonu'daki turizm sektöründeki çalışan kişilerin de } \\
\text { yabancı dil öğrenmeleri ve bildikleri yabancı dil sayılarını artırmaları önemli } \\
\text { olmaktadır. Bu durum misafir memnuniyetini artıracak ve şehrin turizm } \\
\text { imajının gelişmesine önemli katkılar sağlayacaktır. }\end{array}$ \\
\hline Tanıtım Faktörü & $\begin{array}{l}\text { Kastamonu ilinin, ülke vatandaşları tarafindan çoğunlukla yeterince } \\
\text { tanınmadığı görülmektedir. İ hakkında daha fazla reklam, tanıtım, } \\
\text { tutundurma faaliyetleri, slogan, jenerik müzik, el kitapları, broşürler, ulusal } \\
\text { ve uluslararası haber kanallarında gündeme getirme (Kastamonu Kenti } 2018 \\
\text { senesinde Türk Dünyası Başkenti olmuştur. Doğal, tarihi ve kültürel } \\
\text { mirasları, etkinlikleri, festivalleri, faaliyetleri Türk Dünyası ülkeleri açısından } \\
\text { tanınma firsatını yakalamış fakat tanıtım faktörü yeterli olmadığı için } \\
\text { tanınırlık oranı çok fazla artmamıştır) ve benzeri çalışmaların oluşturulması } \\
\text { ve yaygınlaştırılması gerekmektedir. Ayrıyeten pek çok kitle iletişim } \\
\text { aracından belirli zaman aralıklarıyla Kastamonu ve turizm konusunda çeşitli } \\
\text { bilgilerin verilmesi gerektiği düşünülmektedir (özellikle inanç turizmiyle } \\
\text { ilgili bilgilerin aktarılması gerekli görülmekle beraber turizmin tüm çeşitleri } \\
\text { hakkında da verilecek bilgilerin oldukça önemli olduğu ifade } \\
\text { edilebilmektedir). Sosyal medya uygulamalarının da daha aktif, etkili ve } \\
\text { verimli kullanılması, tanıtım açısından çok geniş kitlelere ulaşmak için } \\
\text { Kastamonu'ya önemli faydalar sağlayacaktır. }\end{array}$ \\
\hline Pazarlama Faktörü & $\begin{array}{l}\text { Kastamonu'da turizm alanında pazarlama çalışmalarının yeterli durumda } \\
\text { olmadığı görülmektedir. İlk önce etkili bir pazarlama stratejisi devreye } \\
\text { sokulup, turizm pazarında rekabet edebilir seviyeye gelmesi gerekmektedir. } \\
\text { Kastamonu'nun turistik ürünleri en iyi şekilde tanitılmalı ve pazarlanmalıdır. } \\
\text { Turizm faaliyetlerinde gösterilen hizmet kaliteleri de pazarlama aşamalarında } \\
\text { oldukça öne çıkmakta ve önemli olmaktadır. }\end{array}$ \\
\hline $\begin{array}{c}\text { Coğrafik Yapı ve İklim } \\
\text { Faktörleri }\end{array}$ & $\begin{array}{l}\text { Kastamonu, çoğunlukla dağlı ve engebeli topraklara sahip olmaktadır. } \\
\text { İkliminin ise; kuzey kesimlerde Karadeniz iklimi, güney kesimlerde ise İç } \\
\text { Anadolu ikliminin olduğu görülmektedir. Y1l içerisinde ise il genelinde } \\
\text { çoğunlukla soğuk hava ve yağışların görüldüğü ifade edilebilmektedir. } \\
\text { Coğrafi yap1 ve iklim faktörleri gibi doğal etmenler turistlerin seyahat } \\
\text { etmeden önce göz önünde bulundurduğu unsurlar olarak öne çıkmaktadır. }\end{array}$ \\
\hline Girişimcilik Faktörü & $\begin{array}{l}\text { Yaratıcı fikirler, yeni plan ve projelerin meydana getirilmesinde etkin rol } \\
\text { oynamaktadır. Girişimcilik alanlarında Kastamonu ili daha çok ilerleme }\end{array}$ \\
\hline
\end{tabular}

December-2020 Vol:5 No:2 International Journal of Turkic World Tourism Studies 


\begin{tabular}{|c|c|}
\hline & $\begin{array}{l}\text { kaydetmelidir. Bu anlamda insanları bilgilendirecek düşünceler, açık ve net } \\
\text { bir şekilde ifade edilmelidir. İnsanların zihinlerinde oluşacak herhangi bir } \\
\text { soru işareti karşıllısız bırakılmamalıdır. Girişimcilik fikirlerini destekleme } \\
\text { konusunda devlet teşvikleri artırılmalıdır. Sürekli gelişen ve değişme gösteren } \\
\text { dünyada yenilikleri ögrenmek önem arz etmektedir. Günümüz, bilgi ve } \\
\text { iletişim çağıdır. Teknolojinin nimetlerinden en iyi biçimde yararlanılması } \\
\text { gerekmektedir. Bu yararlanmalar da girişimcilik fikirleri üzerine } \\
\text { aksettirilmelidir. }\end{array}$ \\
\hline Yerel Halk Faktörü & $\begin{array}{l}\text { Yerel halk turizm konusunda bilinçlendirilmelidir. Kastamonu yerel halkının } \\
\text { bir bölümü turistleri misafir olarak görürken, bazıları ise sadece gelir getiren } \\
\text { kişi olarak görmelidir. Turistlerin sadece gelir getiren kişi olarak görülmesi } \\
\text { beraberinde birçok olumsuz sonuçları da doğurmaktadır. Turistler sadece } \\
\text { maddi kazanç olarak görülmemelidir. Durum böyle olduğunda ise etkili } \\
\text { iletişimin kurulamaması kaçınılmaz olmaktadır. Kastamonu yerel halkı, } \\
\text { turistleri bekleyici, kendi içerisine kapanı bir durumda olmamalı, aksine } \\
\text { davetkâr olup, şehri cezbedici bir şekilde çekici unsurlarıyla insanlara } \\
\text { tanıtmalıdır. Yerel halkın, çekingen olmayıp, dominant özelliklere sahip } \\
\text { olması gerektiği düşünülmektedir. }\end{array}$ \\
\hline Turizm Paydaşları Faktörü & $\begin{array}{l}\text { Resmi kurumlar ve özel kuruluşlar, sivil toplum örgütleri, işletmeler, } \\
\text { girişimciler ve yerel halk turizm alanında iş birliği içerisinde çalışmaların } \\
\text { yürütmelidirler. İş birliği sağlamak gerçekleştirilecek / gerçekleştirilen } \\
\text { faaliyetlerin daha geniş kitleler tarafindan tanınmasına katkı sağlayacaktır. } \\
\text { Zamandan ve masraflardan tasarruf edilmesini sağlayacaktır. Olayların perde } \\
\text { arkasındaki problemler daha iyi tespit edilip, ona uygun olan daha iyi } \\
\text { önlemler alınacaktır. }\end{array}$ \\
\hline İstihdam Olanakları Faktörü & $\begin{array}{l}\text { Şehirde istihdam olanakları yeterli olmamaktadır. Şehirde işsiz olan kişilerin } \\
\text { sayısının çok olduğu görülmektedir. İnsanlar temel gereksinimlerini } \\
\text { karşıladıktan sonra, başka konulara karşı daha akılcı fikirlerde } \\
\text { bulunabilmekte ve bilinçli davranabilmektedir. }\end{array}$ \\
\hline Sağlık Faktörü & $\begin{array}{l}\text { Bir çevrede etkisini gösteren hastalıklar (günümüzde Koronavirüs salgın } \\
\text { hastalığı vakası görülmekte ve dünya genelinde yayılma özelliği } \\
\text { gösterebilmektedir) turizm faaliyetlerini yavaşlatabilmekte, hatta durdurma } \\
\text { noktasına getirebilmektedir. Seyahat edilecek yerlere yönelik birtakım } \\
\text { önlemler alınmaktadır. Kişiler, kişisel temizliklerine daha çok önem } \\
\text { vermektedir. Salgın hastalıklardan dolayı, seyahat alanında, illere ve ülkeye } \\
\text { giriş ve çıkışların kısıtlandığı veya tamamen yasaklandığı görülebilmektedir. } \\
\text { Kastamonu'ya giriş ve çıkış işlemleri salgın hastalıklardan dolayı yavaşlamış, } \\
\text { insanlar tedirgin ve stresli olmuştur. Hastalıkların yaşanması, turizm } \\
\text { sektörünü derinden etkilemektedir ve ekonomik sıkıntıların baş göstermesine } \\
\text { sebebiyet vermektedir. Salgın hastalığın yaşandığı bu süreçte çoğu insan } \\
\text { maddi-manevi zarar görmüş hala da zarar görmeye devam etmektedir. Sağlı, } \\
\text { turizmi doğrudan ve derinden etkileyen bir faktör olmaktadır. Insanlar } \\
\text { sağlıklarını daha fazla riske atmamak için turizm etkinliklerine katılmak } \\
\text { istemeyeceklerdir. Sağllk bir insan için en değerli unsurlardan bir tanesidir. } \\
\text { Sağlıklı bir yaşam sürmek için herkes üstüne düş̧en görev ve sorumlulukların } \\
\text { bilincinde olmall, insanlar bu salgın sürecinde ellerinden gelenin en iyisini } \\
\text { yapmaya azami gayret göstermelidir. }\end{array}$ \\
\hline Doğal ve Beşeri Faktörler & $\begin{array}{l}\text { Deprem, sel, çı̆̆, heyelan, çevrenin tahrip edilmesi, doğal, tarihi ve kültürel } \\
\text { yapılara zarar verilmesi, insanlar arasında ilişkilerin zedelenmesi, turizmi } \\
\text { dolayısıyla da inanç turizmini olumsuz etkilemektedir. Kastamonu'da } \\
\text { bulunan tarihi konaklara daha çok yenileme çalışmaları yapılmalıdır. Bunları } \\
\text { yaparken de doğal ve estetik mimarisine zarar verilmemeye özen } \\
\text { gösterilmelidir. }\end{array}$ \\
\hline $\begin{array}{c}\text { Altyapı ve Üst Yapı } \\
\text { Faktörleri }\end{array}$ & $\begin{array}{l}\text { Şehrin turistik arz kaynaklarının (otel, lokanta, restoran, kafe, pansiyon, } \\
\text { kongre merkezleri vb. alanların) artırılması gerekmektedir. Bu alanlara daha } \\
\text { çok yatırım yapılmalıdır. Turizm sektöründe çalışan kişiler çok yönlü } \\
\text { yeteneklere sahip olmalıdır. }\end{array}$ \\
\hline Eğitilmiş İşgücü Faktörü & $\begin{array}{l}\text { İl genelinde turizm sektöründe çalışan personellerin çoğu yabancı dil } \\
\text { bilmemektedir. Şehirde turizm sektöründe çalışanların bir bölümü, üniversite } \\
\text { mezunu olmamaktadır. Hal böyle olunca, konusunda bilgi sahibi olunmaması, } \\
\text { uzmanlık alanlarının turizm olmaması, turizm sektörünü sekteye } \\
\text { uğratmaktadır. Turizm açısından çeşitli bilgi, eğitim, beceri ve yeteneklere } \\
\text { sahip olan kişilerin turizm sektöründe çalışması gerektiği düşünülmektedir. } \\
\text { Aksi takdirde ise turizm sektöründen daha fazla gelirlerin sağlanamayacağ1 }\end{array}$ \\
\hline
\end{tabular}




\begin{tabular}{|c|c|}
\hline & ifade edilebilmektedir. \\
\hline Ulaşım Faktörü & $\begin{array}{l}\text { İnanç destinasyonlarına ulaşım konusunda çeşitli sıkıntılar görülmektedir. } \\
\text { Şehirdeki bazı inanç destinasyonlarına otobüs ile ulaşım sağlanamamaktadır. } \\
\text { Örneğin Şeyh Şaban-1 Veli Külliyesi’ne şehir içi otobüs ile seyahat etmek } \\
\text { mümkün olmamaktadır. Bu tür yerlerin otobüslerin güzergâhında yer alması } \\
\text { gerekmektedir. }\end{array}$ \\
\hline İletişim Faktörü & $\begin{array}{l}\text { Şehir içerisinde zaman zaman iletişimde kopukluklar yaşanabilmektedir. } \\
\text { Bazen telefon çekmemesi ve bazen de internet çekmemesi gibi sorunlar } \\
\text { gerçekleşebilmektedir. İnsanlar kendilerini ifade etme gereksinimi } \\
\text { duymaktadırlar. İletişim problemlerinin meydana gelmesiyle, turistlerde } \\
\text { memnuniyetsizlik ve tatminsizlik görülebilmektedir. }\end{array}$ \\
\hline Finansal Faktör & $\begin{array}{l}\text { Turizm, emek yoğun bir sektör olarak diğer sektörler arasında öne } \\
\text { çıkmaktadır. Şehirdeki mevcut işletmeler finansal planlama gerçekleştirirken } \\
\text { meydana gelebilecek krizlere ve turistik taleplerin gidişatına göre bir strateji } \\
\text { izlemelidir. Kastamonu'daki çoğu işletme finansman sağlama konusunda } \\
\text { çeşitli zorluklar ile karşıllaşmaktadır. }\end{array}$ \\
\hline Önyargı Faktörü & $\begin{array}{l}\text { Şehre karşı önyargılı bir tutumun olduğu görülmektedir. Kastamonu ve } \\
\text { turizm denildiğinde insanların arasında önyargı oluşmaktadır. Kastamonu'da } \\
\text { turizm denildiğinde birçok insan tarafından çoğunlukla bir bağlantı } \\
\text { kurulamamaktadır. Kastamonu'da turizmin gelişmesi zordur, Kastamonu } \\
\text { yeterince tanınmıyor, Kastamonu turizm faaliyetlerinin gelişmesi için } \\
\text { gerçekleştirilen çalışmalar etkili değil ve turizm alanında kat etmesi gereken } \\
\text { daha çok yol var gibi söylemlere zaman zaman rastlamak mümkün } \\
\text { olmaktadır. Kastamonu ili, dini ve inanç yönleri ağır basan bir il olmaktadır. } \\
\text { İnaç turizmi ile ilgili önemli potansiyel kaynağı bünyesinde } \\
\text { barındırmaktadır. İnsanların düşüncelerinde ve algılarında şehir kimliğini } \\
\text { olumsuz etkileyecek durumlara (sosyal, psikolojik, çevresel, ekonomik vb. } \\
\text { açılardan olumsuz bir şekilde ortaya çıacak durumlara) karşı tedbirler } \\
\text { alınması ve söz konusu tedbirlerin artırılması önem arz etmektedir. }\end{array}$ \\
\hline
\end{tabular}

\section{TARTIŞMA VE SONUÇ}

Kastamonu ilinde inanç turizmi açısından çok önemli inanç destinayonlarına sahip bir kent olmakta ve Kastamonu, Evliyalar Kenti (yaklaşık 17 bin evliyanın yaşamış olduğu bir şehir olarak tanınmaktadır) olarak tanınmaktadır. Şehir içerisinde inanç turizmi denilince akıllara Şeyh Şaban-1 Veli gelmektedir. Bu önemli şahsiyet Anadolu'nun dört manevi direğinden bir tanesi olmaktadır ve Şeyh Şaban-1 Veli Külliyesi, inanç turizmi amaçlı gerçekleştirilen ziyaretler için de önemli bir konuma sahip olmaktadır. Fakat şehirde inanç turizminin gelişmesinde birtakım engeller söz konusu olmaktadır. $\mathrm{Bu}$ engellerin aşılmasıyla birlikte Kastamonu ili inanç turizmi alanında daha da gelişme göstermiş olacak ve şehirde gerçekleşen inanç turizmi faaliyetleri insanlar arasında daha bilinir hale gelecektir. Kastamonu; yabancı dil faktörü, tanıtım faktörü, pazarlama faktörü, coğrafik yapı ve iklim faktörleri, girişimcilik faktörü, yerel halk faktörü, turizm paydaşları faktörü, istihdam olanakları faktörü, sağlık faktörü, doğal ve beşeri faktörler, altyap1 ve üst yapı faktörleri, eğitilmiş işgücü faktörü, ulaşım faktörü, iletişim faktörü, finansal faktör, önyargı faktörü gibi faktörlere dikkat edip, gerekli tedbirleri aldığ 1 takdirde inanç turizmi alanındaki olumsuzlukları ortadan kaldırıp, bu alanda Türkiye'de önde gelen şehirler arasında yerini alabilecektir. Turizm sektöründe yabancı dil bilinmesi artık zorunlu bir hal almış bulunmaktadır. Kastamonu'ya seyahat eden turistlerin memnuniyetini kazanmak, istek ve gereksinimlerini en iyi biçimde karşılamak için yabancı dil öğrenilmeli ve akıcı bir şekilde konuşulmalıdır. Şehir kimliği, dijital platformlarda en cezbedici ve unutulmayacak biçimlerde insanların zihinlerine ilmek ilmek dokunmalıdır. Etkili pazarlama kanallarının kullanılması ve yaygınlaştırılması hususunda herkes üzerine düşen sorumlulukları yaptığı takdirde çok geniş kitlelere ulaşım sağlanabilecek, böylece şehir imajına yönelik iyi algıların meydana gelmesi sağlanmış olacaktır. Kastamonu'da inanç turizmi denilince bu noktada turizm paydaşlarının izlediği yol çok önemli olmaktadır. Turizm paydaşları, inanç turizminde Kastamonu'nun gelişme göstermesi için elbirliğiyle ve eşgüdümlü bir şekilde çalışmalar gerçekleştirmelidir. Şehirde gerçekleşen inanç turizmi faaliyetlerinin önündeki engellerin ve olumsuzlukların ortadan kaldırılması, inanç turizminin gelişmesini sağlayacaktır. 
İnanç turizminin gelişmesi ile de şehirdeki turizmde canlanma meydana gelecektir. Kastamonu şehrinde gerçekleşen diğer turizm çeşitlerini de olumlu yönde etkileyeceği, gelişmeler ve yenilikler yaratacağı tahmin edilmektedir.

Araştırma neticesinde ortaya çıkan, faydalı olabileceği tahmin edilen öneriler şu şekildedir:

- Kastamonu ilinde bulunan inanç destinasyonlarının tümüne toplu taşıma araçlarıyla erişim sağlanabilmelidir.

- Kastamonu yerel halkı turizm konusunda daha çok bilinçlendirilmelidir.

- Turizm paydaşları el ele verip, şehirdeki turizmi 12 aya yayma çalışmalarına hız kazandirmalıdır.

- Kastamonu turizm arzı kapasitesi artırılmalıdır ve bu alanlarda yeterli kaynaklar sağlanmalı, devlet teşvikleri artırılmalıdır.

- Şehirde bulunan insanlar turistlere karşı davetkâr olmalıdır.

- İnanç turizmi hususunda Kastamonu apayrı bir yere sahip olmaktadır. Şehir, Evliyalar Kenti olarak tanınmaktadır. Kastamonu, birçok doğal, kültürel ve tarihi değerlere sahiptir. Fakat tanıtım faaliyetleri yetersiz olduğu için beklenen ziyaretçi sayılarına ulaşılamamaktadır.

- Kastamonu'nun inanç turizmi alanında yeniliklere ve gelişmelere ihtiyacı bulunmaktadır. Şöyle ki; girişimcilik alanında daha çok ilerlemeler kaydetmesi gerekmektedir. İnsanlar arasında girişimcilik faaliyetlerini (turizm odaklı olmak üzere) ön plana çıkaran gelişmeler, televizyon ve radyo gibi kitle iletişim araçlarından ifade edilmesi sağlanmalıdır.

\section{KAYNAKÇA}

Akkılıç, M. E. ve Günalan, M. (2007). Edremit Körfezi’nde Turizm Problemleri ve Çözüm Önerileri Üzerine Bir Araştırma. Selçuk Üniversitesi Karaman İ.İ.B.F. Dergisi, 12 (9), 121-127.

Aşkar, M. (2012). Ömeru'l-Fuâdî’nin Menâkıbnâmesine Göre Şeyh Şa'bân-1 Velî’nin Tasavvufî Şahsiyetine Bir Bakış. I. Uluslararası Şeyh Şa'bân-ı Velî Sempozyumu, 14-6 Mayıs 2012, $117-$ 146.

Avcı, M. (1990). Kastamonu'nun Turizm Potansiyeli. (Yayımlanmamış Yüksek Lisans Tezi). İstanbul Üniversitesi, Sosyal Bilimler Enstitüsü, İstanbul.

Avcıkurt, C. (2009). Turizm Sosyolojisi, Genel ve Yapısal Yaklaşım. Ankara: Detay.

Çakıcı, C., Atay, L. ve Aksu M. (2008). Bozcaada Turizminin Değerlendirilmesine Yönelik Bir Kamuoyu Araştırması. 3. Balıkesir Ulusal Turizm Kongresi, 17-19 Nisan 2008, Balıkesir.

Demirkol, Ş. (2004). Turizm Arz Kaynaklarının Tanıtımında Bilgi Teknolojilerinin Kullanımı: Sakarya Tanıtım CD'si Örneği. 1. Balıkesir Ulusal Turizm Kongresi, 15-16 Nisan 2004. Balıkesir.

Duman, T. ve Öztürk, A. B. (2005). Yerli Turistlerin Mersin Kızkalesi Destinasyonu ve Tekrar Ziyaret Niyetleri İle İlgili Algılamaları Üzerine Bir Araştırma. Anatolia: Turizm Araştırmaları Dergisi, $16(1), 9-23$.

Griffiths, M. (2011). Those Who Come to Pray and Those Who Come to Look: Interactions Between Visitors and Congregations. Journal of Heritage Tourism, 6(1), 63-72.

Güngör, E. (1972). Evliyası Olmayan Yerde Türk de Yok Demektir!, Töre Dergisi, 19, 8-12.

Güzel, F. Ö. (2010). Turistik Ürün Çeşitlendirmesi Kapsamında Yeni Bir Dinamik: İnanç Turizmi. Vizyoner Dergisi, 2(2), 87-100.

Hacıoğlu, N. (1991). Turizmde Yeni Gelişmeler ve Sorunlar. Turizm Dünyası Dergisi, 22-24.

Hacıoğlu, N., Kaşlı, M., Şahin, S., Tetik, N. (2008). Türkiye'de Turizm Eğitimi. Ankara: Detay Yayıncilik. 
İlban, M. O. ve Altay, H. (2008). Antakya'nın Destinasyon İmajına Yönelik Bir Araştırma. 3. Balıkesir Ulusal Turizm Kongresi, 17-19 Nisan 2008, Balıkesir.

İlban, M. O. ve Kaşl1, M. (2011). Altınoluk’ta Turizmin Gelişmesini Etkileyen Sorunlar: Hizmet İşletmelerinde Bir Araştırma. Çağdaş Yerel Yönetimler, 20(1), 27-52.

Jamieson, W. (2006). Community Destination Management in Developing Economies. London: The Haworth Hospitality Press.

Karaman, S. ve Usta, K. (2006). İnanç Turizmi Açısından İznik ve Bir Uygulama Çalışması. III. Balıkesir Ulusal Turizm Kongresi, 20-22 Nisan Balıkesir, 473-489.

Kaşl1, M. (2006). Yerli Turistlerin Kaplıca Merkezlerini Ziyaret Nedenleri ve Beklentileri Üzerine Gönen'de Bir Araştırma. 2. Balıkesir Ulusal Turizm Kongresi, 20-22 Nisan 2006, Balıkesir.

Kaşl1, M. ve Karataban, Ö. (2008). İstanbul Menkul Kiymetler Borsası'nda İşlem Gören Turizm İşletmelerinin Oranlar Yoluyla Analizi. 3. Ballkesir Ulusal Turizm Kongresi, 17-19 Nisan 2008, Balıkesir.

Kelly, G. A. (1982). Faith, Freedom, and Disenchantment: Politics and the American Religious Consciousness. Daedalus, 127-148.

Kırış, Ş. (2011). Peygamber Sevgisinin Bir Tezahürü: Teberrük. Marife Dini Araştırmalar Dergisi, 11(1), 19-30.

Kuter, N. ve Erdoğan, E. (2006). Yalvaç, Pisidia Antiocheia Antik Kenti Ve Çevresinin Peyzaj Özellikleri Ve Turizm Açısından Değerlendirilmesi. Türkiye Ormancıllk Dergisi, 7(1), 111-123.

Levin, S. (1979). Understanding Religious Behavior. Journal of Religion and Health, 18(1), 820.

Liu, A. (2006).Tourism In Rural Areas: Kedah, Malaysia. Tourism Management, 27(5), 878-889.

Mattila, A. S., Apostolopoulos, Y., Sonmez, S., Yu, L. ve Sasidharan, V. (2001). The Impact of Gender and Religion on College Students' Spring Break Behavior. Journal of Travel Research, 40(2), 193-200.

Nepal, S. K. (2008). Residents' Attitudes to Tourism in Central British Columbia, Canada. Tourism Geographies, 10(1), 42-65.

Nolan, M. L. ve Nolan, S. (1992). Religious Sites As Tourism Attractions in Europe. Annals of Tourism Research, 19(1), 68-78.

Ozanoğlu, İ. (1966). Şa'bân-1 Velî Hayatı, Eserleri ve Külliyyesi, Kastamonu.

Poria, Y., Butler, R. ve Airey, D. (2003). The Core of Heritage Tourism. Annals of Tourism Research, 30(1), 238-254.

Rinschede, G. (1992). Forms of Tourism. Annals of Tourism Research, 19, 5-67.

Rzazade, H., Guzel, Ö. ve Ehtiyar, R. (2018). Azerbaycan'da İnanç Turizminin Mevcut Durumunun Değerlendirilmesine Yönelik Nitel Bir Araştırma. Journal Of Awareness, 3(5), 427-446.

Shackley, M. (2002). Space, Sanctity and Service; The English Cathedral as Heterotopias. International Journal of Tourism Research, 4(5), 345-352.

Sznycer-Taub, M. (2009). Community Capacity in Public Health, Application. Retrieved from http://miriamsznycertaub.myefolio.com/uploads/miriam\%20sznycertaub_community\%20capac ity.pdf.

Tala, M. L. ve Padurean, A. M. (2008). Dimensions of Religious Tourism. Amfiteatru Economic, 242253.

Tosun, C. ve Bilim, Y. (2004). Hatay'ın Turistik Bir Şehir Olarak Pazarlanması. 1. Balıkesir Ulusal Turizm Kongresi, 15-16 Nisan 2004, 269-288.

Tunçsiper, B. ve İlban, M. O. (2006). Turizm İşletme Belgeli Otel İşletmelerinin Pazarlama Sorunları: Balıkesir İlinde Bir Alan Araştırması. Anadolu Üniversitesi Sosyal Bilimler Dergisi, 6, (1), $225-244$.

December-2020 Vol:5 No:2 International Journal of Turkic World Tourism Studies 
Yıldırım, B. (2019a). Nebî b. Turhan es-Sinobî (ö.936/1530)'nin Tasavvufî Düşünceye Yönelttiği Tenkitler. Akra Kültür Sanat ve Edebiyat Dergisi, 7(19), 91-110.

Yıldırım, B. (2019b). Kesret Çarşısında Bir Vahdet Dükkânı Köstendilli Süleyman Şeyhî Efendi Hayatı Eserleri ve Tasavvufí Görüşleri. İstanbul: Büyüyen Ay Yayınları.

\section{Sözlü Kaynaklar}

KK1: Muharrem Avc1, Doktora, Akademisyen, 15.10.2020, Muharrem Avcı'nın Odası. 